\title{
Removal of COD and BOD from biologically treated municipal wastewater by electrochemical treatment
}

\author{
Arun K umar Sharma* and A. K . Chopra \\ Department of Zoology and Environmental Sciences, Gurukula Kangri University, Haridwar-249404 (Uttarakhand), \\ INDIA \\ *Corresponding author. E-mail: asharma.env@gmail.com
}

Received: November 27, 2013; Revised received: D ecember 4, 2013; Accepted: D ecember 5, 2013

\begin{abstract}
The present investigation observed the effect of current density (CD), operating time (OT), inter electrode distance (IED), electrode area (EA), initial pH and settling time (ST) using Fe-Fe electrode combination on the removal of chemical oxygen demand (COD) and biochemical oxygen demand (BOD) from biologically treated municipal wastewater (BTMW) of Sewage Treatment Plant (STP). The maximum removal of COD (92.35\%) from BTMW was found with the optimum operating conditions of CD $\left(2.82 \mathrm{~A} / \mathrm{m}^{2}\right)$, OT $(40 \mathrm{mins}$.), IED $(0.5 \mathrm{~cm})$, EA $(160$ $\mathrm{cm}^{2}$ ), initial $\mathrm{pH}(7.5)$ and ST (60 min.), while the maximum removal of BOD $(84.88 \%)$ was found with the ST (30 min.) at the same operating conditions. There was no need of $\mathrm{pH}$ adjustment of the BTMW during ET as the optimal removal efficiency was close to the $\mathrm{pH}$ of 7.5. Under optimal operating conditions, the operating cost was found to be $54.29 \mathrm{Rs} . / \mathrm{m}^{3} / 1.08 \mathrm{US} \$ / \mathrm{m}^{3}$ in terms of the electrode consumption $\left(78.48 \times 10^{-5} \mathrm{~kg} \mathrm{Al} / \mathrm{m}^{3}\right)$ and energy consumption $\left(108.48 \mathrm{Kwh} / \mathrm{m}^{3}\right)$
\end{abstract}

Keywords: Biologically treated municipal wastewater, Current density, BOD, COD, Electrochemical treatment, Electrode consumption, Energy consumption

\section{INTRODUCTION}

Sewage treatment consists of an item that deserves ample documentation due to the environmental impact caused by such wastewater if directly discharged into water bodies. In addition, due to an increase in the scarcity of clean water (Aiyuk et al., 2006), there is need for proper management of available water resources. Some of the goals of environmental protection and resource conservation concepts are the re-use of treated wastewater, residues emanating there from and other treatment by-products (Lettinga et al., 2001 and Yi, 2001). Treatment of industrial and domestic wastewater to avoid environmental pollution, especially contamination of pure water resources has become national and international issue. Innovative, cheap and effective method of purifying and cleaning wastewater before discharging into other water system is the desperate need of the hour (Niam et al., 2007). Conventionally biologically treated sewage water may not meet the requirements for discharge and permissible limit of wastewater for its reuse.

Electrolytic Technology (ET) has emerged as an interesting subject for different groups of researchers which are looking for new technologies for wastewater treatment. Basically, ET under the proceeds of in situ generation of coagulants allows better efficiency of the abatement of the organic substrates and avoids the need of transportation and storage. ET has been investigated, with particular efforts, since the end of eighties, by testing different anodic and cathodic materials for the treatment of sewage water. The mechanism of electrolytic treatment involves stabilization and flotation of contaminants controlled by various factors such as electrode material, voltage, operating time, coagulant and bubble generation from the electrodes. Robust and compact instrumentation is easily achievable in the electrochemical techniques and hence, it has the potential to replace sophisticated processes that require large volumes and/or number of chemicals and massive containers that are present in a typical wastewater treatment plant (WWTP) (Mollah et al., 2004).

Besides, biodegradability of wastewater can usually be improved with electrolytic treatment. Electrochemical process has been proven to be very effective in removing contaminants from water and is characterized by reduced sludge production, no requirement for chemical use and ease of operation (Rajeshwar et al., 1994). During Electrocoagulation (EC), the coagulant is generated in situ by electrooxidation of an anode of appropriate material. Charged ionic species are removed from wastewater by allowing ions to react with oppositely charged ions, or with flocs of metallic hydroxides generated within the effluent (Mollah et al., 2001). The ISSN : 0974-9411 (Print), 2231-5209 (Online) All Rights Reserved ๑ Applied and Natural Science Foundation www.ansfoundation.org 
present study has been focused to find out the treatability of biologically treated municipal wastewater (BTMW) by electrolytic treatment at various operating conditions using $\mathrm{Fe}-\mathrm{Fe}$ electrodes.

\section{MATERIALS AND METHODS}

Collection of wastewater samples: The samples of BTMW were collected from the outlet of activated sludge process (ASP) of the sewage treatment plant (STP), Jagjeetpur, Haridwar (Uttarakhand), India and brought to the laboratory and then used for ET using $\mathrm{Fe}-\mathrm{Fe}$ electrode combination. The $\mathrm{pH}$ of BTMW was adjusted before the electrochemical process and was maintained by adding the required amount of $\mathrm{H}_{2} \mathrm{SO}_{4}(1 \mathrm{M})$ or $\mathrm{NaOH}$ (1 M).

Electrolytic experimental set up: A rectangular Reactor with external dimensions of height $=30 \mathrm{~cm}$, width $=7 \mathrm{~cm}$, length $=11 \mathrm{~cm}$ and wall thickness $=10 \mathrm{~mm}$ constructed with glass with a capacity of 2.0 liters sample was used. Each time, the BTMW sample of 2.0 liters was collected and placed in an electrolytic Reactor. Fe-Fe electrode combination was connected to their respective anode and cathode leading to the D.C. Power supply (LMC electronics, India $0-500 \mathrm{~V}$ and 0- $2 \mathrm{~A}$ ) and energized for a required duration of time at different voltages and currents. All the experiments were performed at room temperature $\left(30 \pm 2^{\circ} \mathrm{C}\right)$ and at a constant stirring speed $(100 \mathrm{rpm})$ to maintain the uniform mixing of BTMW sample during the ET. Before conducting an experiment, the electrodes were washed with water, dipped into diluted $\mathrm{HCl}(5 \% \mathrm{v} / \mathrm{v})$ for 5 mins., thoroughly washed with water and then finally rinsed twice with distilled water. Electrodes were dipped into BTMW sample with different surface areas $\left(80 \mathrm{~cm}^{2}, 120 \mathrm{~cm}^{2}\right.$ and $\left.160 \mathrm{~cm}^{2}\right)$ and different electrode distances $(0.5 \mathrm{~cm}, 1.0 \mathrm{~cm}, 1.5 \mathrm{~cm}, 2.0 \mathrm{~cm}$ and 2.5 $\mathrm{cm}$ ). The different voltages (5 to 40 volts) were passed for different operating times $(10-80 \mathrm{~min})$. After passing the particular voltage for a particular time period i.e. after each batch experiment, the sample was taken for the different settling times (30,60 and 90 mins.) as stated earlier (Chopra and Sharma, 2012).

A nalytical methods: The chemical oxygen demand (COD) and biochemical oxygen demand (BOD) of wastewater were analyzed before and after the ET following the standard methods for examination of water and wastewater (APHA, 2005). The calculation of COD and BOD of removal efficiencies after ET was carried out using the formula:

$$
\mathrm{CR} \%=\frac{\mathrm{Co}-\mathrm{C}}{\mathrm{Co}} \times 100
$$

Where $\mathrm{C}_{0}$ and $\mathrm{C}$ are concentrations of wastewater before and after electrolysis.

$\mathrm{K}$ inetic study: The rate of removal of COD and BOD are represented by the following first-order mechanism (Ashtoukhy and Amin, 2010).

$\ln \left(\frac{\mathrm{C}_{0}}{\mathrm{C}_{\mathrm{t}}}\right)=\mathrm{kt}$

Where $\mathrm{C}_{0}$ - initial concentration $(\mathrm{mg} / \mathrm{L}), \mathrm{C}_{\mathrm{t}}$ - final concentration with respect to time, and t- the time (min) and $\mathrm{k}$ - the rate constant ( $\left.\mathrm{min}^{\prime \prime}\right)$ for COD and BOD for ET using Fe-Fe electrode combination.

\section{RESULTS AND DISCUSSION}

The present study indicated that BTMW before treatment had $\mathrm{pH}(7.8 \pm 0.36)$, conductivity $(695 \pm 46.48 \mu \mathrm{S})$, total dissolved solids (TDS) $(410.6 \pm 43.75 \mathrm{mg} / \mathrm{l}), \mathrm{COD}$ $(112.56 \pm 8.75 \mathrm{mg} / \mathrm{l})$ and BOD $(79.45 \pm 6.89 \mathrm{mg} / \mathrm{l})$. The percent removal of COD and BOD from BTMW using Fe-Fe electrode combination in EC process at different operating conditions such as current density (CD), operating time (OT), inter electrode distance (IED), electrode area (EA), initial $\mathrm{pH}$ and settling time (ST) is indicated in Figs.1- 6.

Effect of CD: It has been established that the current not only determines the coagulant dosage rate but also the bubble production rate and the fluid regime (mixing) within the reactor (Holt et al., 2002). CD is an important operating factor influencing the performance of electrochemical process which determines the coagulant dosage (Tezcan et al., 2006). This is ascribed to the fact that at high CD, the extent of anodic dissolution of aluminum increases, resulting in a greater amount of precipitate for the removal of pollutants. Moreover, bubble generation rate increases and the bubble size decreases with increasing $\mathrm{CD}$. These effects are both beneficial for high pollutant removal by $\mathrm{H}_{2}$ flotation (Kobya et al., 2006).

The present study indicated that removal efficiency of COD and BOD increased progressively with an increase in the CD from 0.16 to $1.68 \mathrm{~A} / \mathrm{m}^{2}$ corresponding to its constant voltages ( 5 to $40 \mathrm{~V}$ ), whereby it exhibited the maximum removal of $\operatorname{COD}(76.9 \%)$ and $\operatorname{BOD}(65.4 \%)$ at the maximum CD $1.80 \mathrm{~A} / \mathrm{m}^{2}$ with the operating conditions of OT (30 min.), IED (1.0 cm), EA ( $\left.80 \mathrm{~cm}^{2}\right), \mathrm{pH}(7.5)$ and ST (30 min.) using Fe-Fe electrode combination (Fig.1). The COD and BOD removal efficiency was found to increase with an increase in the $\mathrm{CD}$. This is due to the fact that an increase in the $\mathrm{CD}$ increases large amount of ferrous ions which subsequently precipitate in the form of hydroxides. The adsorption of $\mathrm{Fe}_{2}^{+}$ion with colloidal pollutants results in the formation of coagulants which can be removed by settling, surface complexation and electrostatic attraction. The present finding is in support of Kobya and Delipinar (2008) who observed that the efficiency of ion production on the anode and cathode increases with increase in CD. Therefore, there was an increase in flocs production in 
Table 1. Economic evaluation (operating cost-OC) using Fe-Fe electrode combination at different EA (Voltage:40 V; OT:40 min.; IED:0.5 cm;pH:7.5 and ST:30 min.).

\begin{tabular}{|c|c|c|c|c|c|c|c|}
\hline \multirow[b]{2}{*}{ EA } & \multicolumn{7}{|c|}{ Fe-Fe el ectrode combination } \\
\hline & $\begin{array}{c}C D \\
\left(A / m^{2}\right)\end{array}$ & $\begin{array}{c}\text { Final } \\
\mathrm{pH}\end{array}$ & $\begin{array}{l}C_{\text {electrode }} \\
\left(\mathrm{kg} / \mathrm{m}^{3}\right)\end{array}$ & $\begin{array}{c}\text { C energy } \\
\left(\mathrm{kWh} / \mathrm{m}^{3}\right)\end{array}$ & $\begin{array}{c}\text { Cost }_{\text {el ectrode }} \\
\left(\mathrm{R} \mathrm{s} . / \mathrm{m}^{3}\right)\end{array}$ & $\begin{array}{l}\text { Cost }_{\text {energy }} \\
\text { (Rs. } / \mathrm{m}^{3} \text { ) }\end{array}$ & $\begin{array}{c}\text { Total } \\
\text { OC }\left(\text { R s. } / \mathrm{m}^{3}\right)\end{array}$ \\
\hline 80 & 1.80 & 8.72 & $50.00 \times 10^{-5}$ & 69.12 & 0.0325 & 34.56 & 34.59 \\
\hline 120 & 2.22 & 9.87 & $61.81 \times 10^{-5}$ & 85.44 & 0.0402 & 42.72 & 42.76 \\
\hline 160 & 2.82 & 10.67 & $78.48 \times 10^{-5}$ & 108.48 & 0.0510 & 54.24 & 54.29 \\
\hline
\end{tabular}

Table2. Rate constant $(\mathrm{k})\left(\mathrm{min}^{-1}\right)$ values at variable voltages using Fe-Fe electrode combination and their correlation coefficients $\left(\mathrm{R}^{2}\right)$.

\begin{tabular}{|c|c|c|c|c|c|c|c|c|c|}
\hline \multirow[b]{2}{*}{ Parameters } & \multirow[b]{2}{*}{ Voltages } & \multicolumn{8}{|c|}{ Fe-Fe electrode combination } \\
\hline & & 5 & 10 & 15 & 20 & 25 & 30 & 35 & 40 \\
\hline \multirow{3}{*}{ BOD } & $\mathrm{K}\left(\mathrm{min}^{-1}\right)$ & 0.0011 & 0.0027 & 0.0049 & 0.0062 & 0.0091 & 0.0130 & 0.0157 & 0.0167 \\
\hline & $\mathrm{R}^{2}$ & 0.8362 & 0.9520 & 0.9593 & 0.9516 & 0.9726 & 0.9825 & 0.9889 & 0.9921 \\
\hline & $\mathrm{K}\left(\min ^{-1}\right)$ & 0.0018 & 0.0038 & 0.0063 & 0.0078 & 0.0098 & 0.0125 & 0.0157 & 0.0174 \\
\hline COD & $\mathrm{R}^{2}$ & 0.9316 & 0.9471 & 0.9811 & 0.9532 & 0.9671 & 0.9801 & 0.9860 & 0.9874 \\
\hline
\end{tabular}

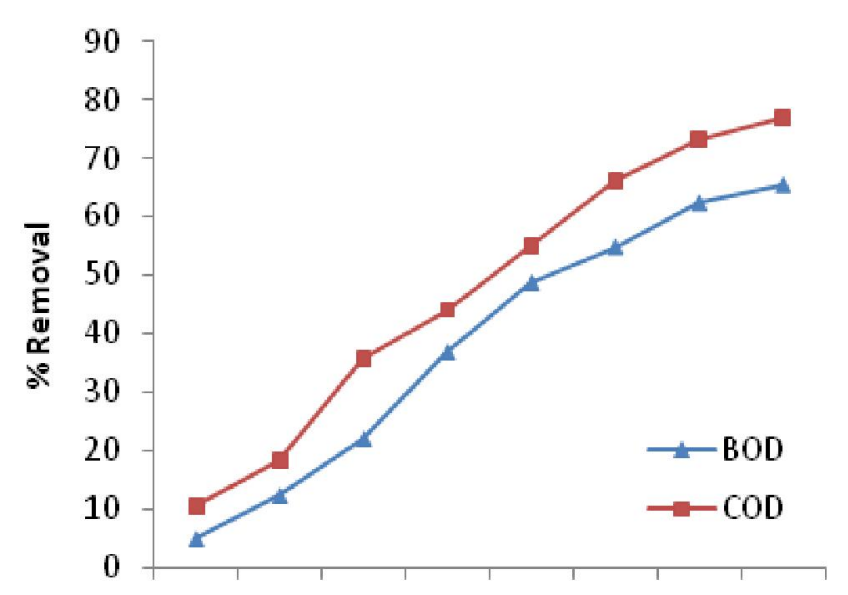

$\begin{array}{llllllll}0.18 & 0.33 & 0.49 & 0.85 & 1.11 & 1.36 & 1.51 & 1.8\end{array}$

\section{$\operatorname{CD}\left(A / \mathrm{m}^{2}\right)$}

Fig. 1. \% removal of $B O D$ and $C O D$ using Fe-Fe electrode combination with different $C D$ at constant operating conditions (OT: $30 \mathrm{~min}$; IED : $1.0 \mathrm{~cm}$; EA: $80 \mathrm{~cm}^{2} ; \mathrm{pH}: 7.5 ; \mathrm{ST}: 30$ min.).

the solution and hence there was an improvement in the efficiency of COD removal of wastewater. Chopra and Sharma (2012) observed that an increase of CD from 1.84 to $7.52 \mathrm{~mA} / \mathrm{cm}^{2}$ increased the TD and BOD removal efficiency from $66.86 \%$ to $83.21 \%$ and 60.19 to $71.29 \%$ respectively at $30 \mathrm{~min}$ electrolytic time using $\mathrm{Al}-\mathrm{Al}$ electrode combination.

Effect of OT: It has been indicated that when the electrolysis period increases, the concentration of metal ions and their hydroxide flocs increase (Daneshvar et al., 2006; Zaroual et al., 2006 and Daneshvar et al., 2007). These enhancing effects are attributed to the increase in the driving force of the electrode reaction and the increase in current and voltage. This is because that the potential is a major driving force for the respective phenomena of interest in electrochemical reactors (Philippe et al., 2003).

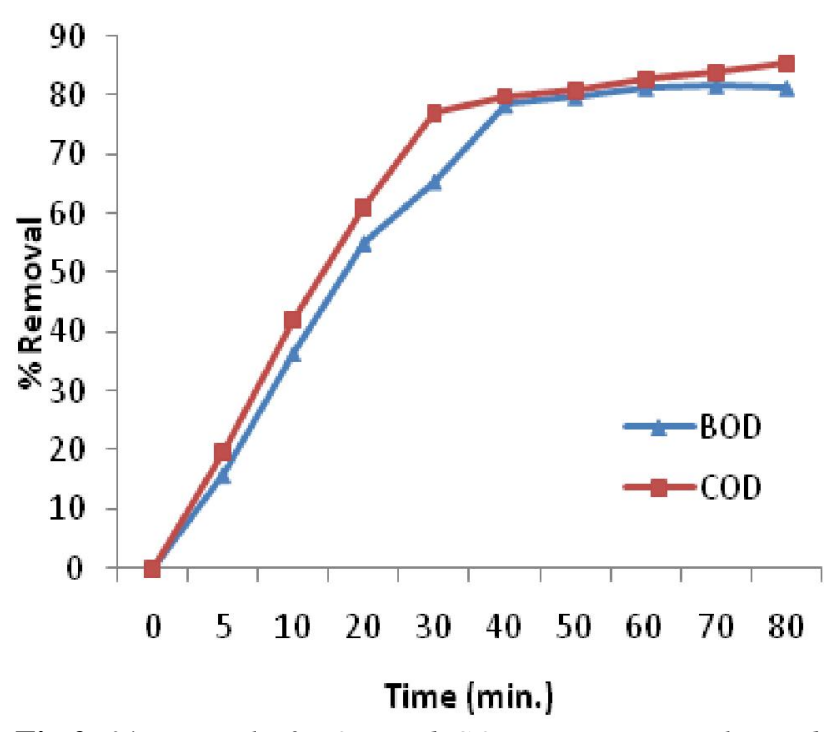

Fig.2. \% removal of $B O D$ and $C O D$ using Fe-Fe electrode combination with different $0 \mathrm{~T}$ at constant operating conditions (CD: $1.80 \mathrm{~A} / \mathrm{m}^{2}$; IED: $1.0 \mathrm{~cm} ; \mathrm{EA}: 80 \mathrm{~cm}^{2} ; \mathrm{pH}: 7.5 ; \mathrm{ST}: 30$ $\min$.$) .$

An increase in electrolytic time or current intensity improves the efficiency of turbidity removal by faster producing hydrolyzed products (Rahmani, 2008).

In present study, it was observed that with an increase in OT, the anodic electrode dissolution led to release of metal ions and the cathode to $\mathrm{OH}^{-}$ions which formed their hydroxides in BTMW during EC. Fig. 2 depicts that the removal of COD and BOD increased progressively with an increase in the OT from 5 to $40 \mathrm{~min}$. with the operating conditions of CD $1.80 \mathrm{~A} / \mathrm{m}^{2}$, IED $1.0 \mathrm{~cm}$, EA 80 $\mathrm{cm}^{2}, \mathrm{pH} 7.5$ and ST $30 \mathrm{~min}$.. The maximum removal of COD $(76.9 \%)$ was at optimum OT of 30 min., while BOD (78.4\%) removal was at optimum OT of $30 \mathrm{~min}$ beyond which there was no significant removal. The present finding is in support of Kobya and Delipinar (2008) who reported that an increase in the OT from 10 to $60 \mathrm{~min}$. 


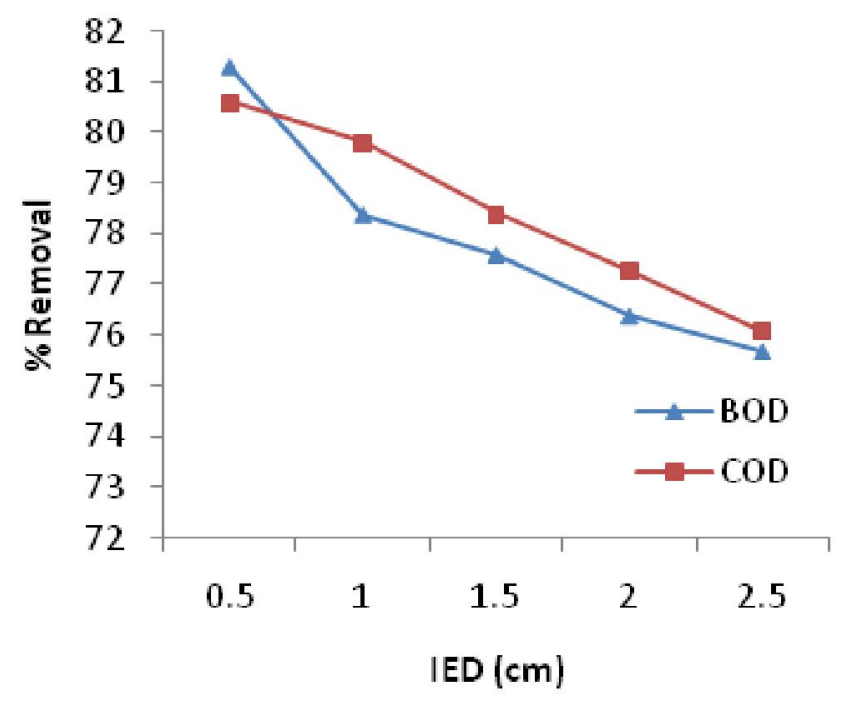

Fig.3. \% removal of $B O D$ and $C O D$ using Fe-Fe electrode combination with different IE $D$ at constantoperating conditions (CD: $1.80 \mathrm{~A} / \mathrm{m}^{2}$; OT: 40mins.; EA: $80 \mathrm{~cm}^{2} ; \mathrm{pH}: 7.5 ; \mathrm{ST}: 30$ $\min$.).

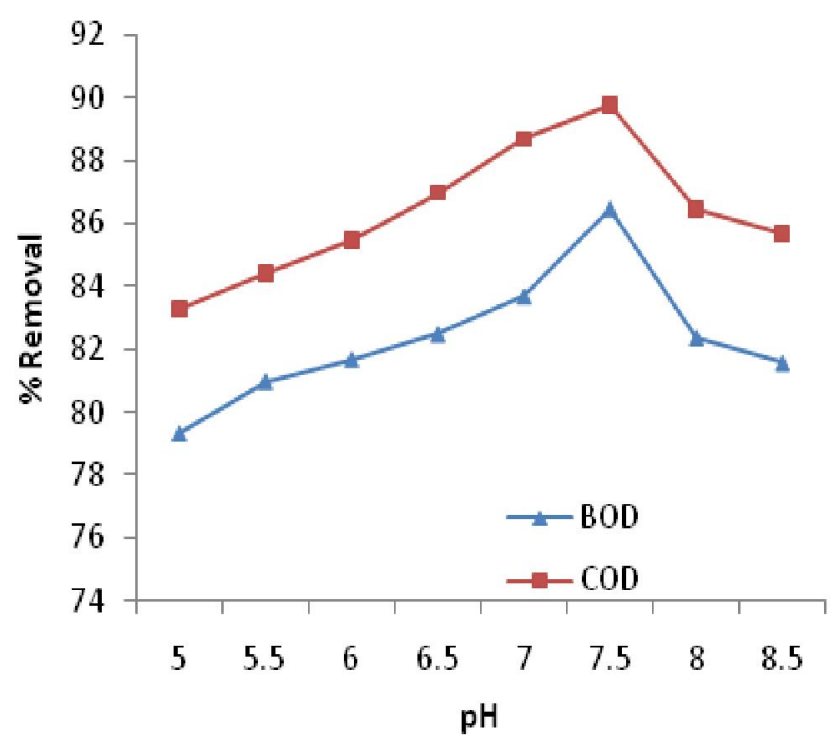

Fig.5. \% removal of $B O D$ and $C O D$ using $F$ e-Fe electrode combination with different $\mathrm{pH}$ at constant operating conditions (CD: $2.82 \mathrm{~A} / \mathrm{m}^{2}$; OT: 40 mins.; IED: $0.5 \mathrm{~cm}$; EA: $160 \mathrm{~cm}^{2}$; $\mathrm{ST}: 30 \mathrm{~min}$.$) .$

resulted in an increase in the removal efficiency of COD, TOC and turbidity during the treatment of the Baker's yeast wastewater by electrocoagulation. Vijayaraghavan et al. (2008) also observed that an increase in the electrolytic treatment period resulted in the decrease of residual COD and BOD concentrations irrespective of the $\mathrm{CD}$ during the ET of latex wastewater. Nasrullah et al. (2012) stated that 4 to $15 \mathrm{~min}$. of OT is sufficient for the nearly complete treatment efficiency of COD, BOD and SS. Chopra and Sharma, (2013) observed removal of $\mathrm{TD}, \mathrm{COD}$ and BOD with the same voltage $(12 \mathrm{~V})$, interelectrode spacing $(2.5 \mathrm{~cm})$ and area of electrode $(160$ $\mathrm{cm} 2$ ) but at a varying time 10 - to $30 \mathrm{~min}$, indicating the

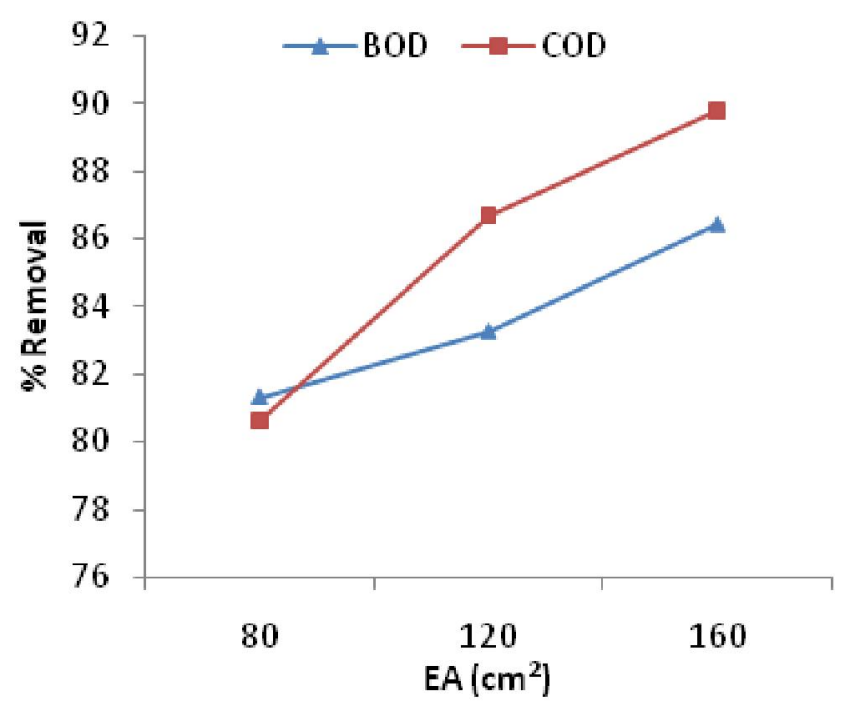

Fig.4. \% removal of $B O D$ and $C O D$ using $F$ e-Fe electrode combination with differ ent $E A$ at constant operating conditions (CD: $2.82 \mathrm{~A} / \mathrm{m}^{2}$; OT: 40 mins.; IED: $0.5 \mathrm{~cm}$; pH: 7.5; ST:30 min.).

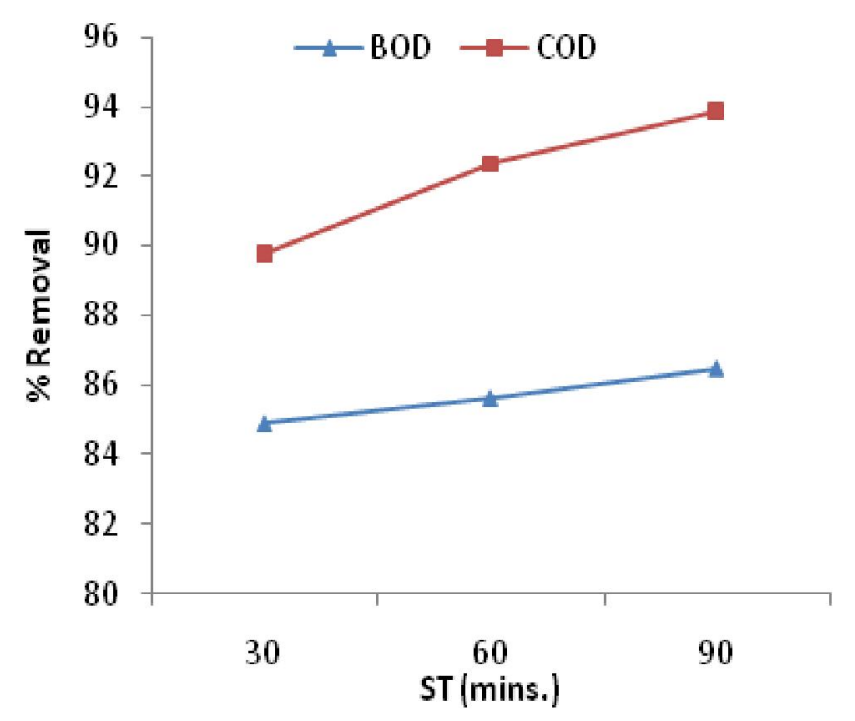

Fig.6. \% removal of BOD and COD using Fe-Fe electrode combination with differentST at constant operating conditions (CD: $2.82 \mathrm{~A} / \mathrm{m}^{2}$; OT: 40 mins.; IED: $0.5 \mathrm{~cm}$; EA: $160 \mathrm{~cm}^{2}$; $\mathrm{pH}: 7.5)$.

superiority of Al-Fe electrode combination over that of $\mathrm{Fe}-\mathrm{Al}$ electrode combination.

Effect of IE D: The removal percentage of COD and BOD increased progressively with decrease in IED from 2.5 to $0.5 \mathrm{~cm}$, whereby it exhibited the maximum removal of COD $(80.6 \%)$ and BOD $(81.3 \%)$ at a short distance of $0.5 \mathrm{~cm}$ between the electrodes, each with an electrode area of 80 $\mathrm{cm}^{2}$ and with the operating conditions of CD $1.80 \mathrm{~A} / \mathrm{m}^{2}$, OT $40 \mathrm{~min}$, EA $80 \mathrm{~cm}^{2}$, pH 7.5 and ST $30 \mathrm{~min}$. (Fig.3). This may be due to the electrostatic attraction between the ions generated from the Fe-Fe electrodes. The low distance $(0.5 \mathrm{~cm})$ between the electrodes showed more attraction of movement of ions generated between the 
electrodes. Similarly Li et al. (2008) have reported that COD decreases with the decrease in distance between electrodes of the same composition. This is because of the reason that the shorter distance speeds up the anion discharge on the anode and improves the oxidation. It also reduces resistance, the electricity consumption and the cost of the wastewater treatment. Ghosh et al. (2008) have stated that with the increase of IED, the percentage removal of dye products from waste water decreases. At a lesser inter-electrode distance, the resistance encountered by current flowing in the solution medium decreases, thereby, facilitating the electrolytic process and results in enhancing the dye removal. Chopra and Sharma (2013) have also observed that the removal percentage of TD, COD and BOD from STS increases progressively with decrease in IED from 10.0 to $2.5 \mathrm{~cm}$ with the use of $\mathrm{Al}-\mathrm{Fe}$ and $\mathrm{Fe}-\mathrm{Al}$ electrode combination. $E$ ffect of EA: The greater EA increases the rate of flock's formation, which in turn influences the removal efficiency. According to Daneshava et al., (2005), an increase of EA causes a corresponding increase of coagulants. The entire effectiveness of the coagulation process depends on the appropriate amount of coagulant. Escobara et al. (2006) have observed logistical relationship between electrode geometric area (AG) and copper removal efficiency and concluded that an increase in copper removal was related to an increase in $\mathrm{AG}$, reaching an optimal value of $35 \mathrm{~cm}^{2}$ with an asymptotic value of near $80 \%$.

In the present study, using $\mathrm{Fe}-\mathrm{Fe}$ combination of electrodes, it was observed that with an increase in EA from 80 to $160 \mathrm{~cm}^{2}$, the $\mathrm{CD}$ increased from 1.80 to $2.82 \mathrm{~A} /$ $\mathrm{m}^{2}$ corresponding to its constant voltage of $40 \mathrm{~V}$ that resulted in an increase in the removal percentage of color, TSS and HR of BTMW .The maximum removal of COD $(89.79 \%)$ and BOD $(86.45 \%)$ was achieved at maximum EA of $160 \mathrm{~cm}^{2}$ with the operating conditions of CD2.82 $\mathrm{A} / \mathrm{m}^{2}$, OT $40 \mathrm{~min}$., IED $0.5 \mathrm{~cm}$., initial $\mathrm{pH} 7.5$ and $\mathrm{ST} 30$ min using $\mathrm{Fe}-\mathrm{Fe}$ electrode combination. The present study supports Chopra and Sharma (2013) who have reported earlier that with a fourfold increase in the EA of Al-Fe from 40 to $160 \mathrm{~cm}^{2}$, there was a maximumremoval of $81.51 \%$ (TD), $74.36 \%$ (COD) and $70.86 \%$ (BOD) from STS with the use of EA of $160 \mathrm{~cm}^{2}$ and at IED of $2.5 \mathrm{~cm}$. $\mathrm{E} f f e c t$ of $\mathrm{pH}$ : The $\mathrm{pH}$ is an important parameter that can influence the electrolytic process. $\mathrm{pH}$ of the medium changes during the process depending on the type of electrode material and initial $\mathrm{pH}$. On the other hand, the electrocoagulation process exhibits some buffering capacity, especially in alkaline medium, which prevents large changes in $\mathrm{pH}$ and shows a decrease of the pollutant removal efficiency ((Lin and Chan, 1997; Chen et al., 2000; Gurses et al., 2002; Kobya et al., 2003), Bayramoglu et al., 2004).

In the present study, the removal efficiency of COD and
BOD with the different initial concentrations of $\mathrm{pH}$ 5-8.5 of BTMW and at operating conditions of CD $2.82 \mathrm{~A} / \mathrm{m}^{2}$, OT $40 \mathrm{~min}$., IED $0.5 \mathrm{~cm}$, EA $160 \mathrm{~cm}^{2}$ and ST $30 \mathrm{~min}$. indicated that the maximum removal of COD $(89.79 \%)$ and BOD $(86.45 \%)$ was at the initial $\mathrm{pH}$ of 7.5 using FeFe electrodes (Fig. 5). After that the removal of these parameters decreased gradually with the increase in $\mathrm{pH}$ of more than 7.5 at constant operating conditions using Al-Al electrodes. Diaz et al. (2003) have established that using $\mathrm{Fe}$ electrodes at different $\mathrm{pH}$ values (range 5-7), the removal of colour, turbidity and COD was lower as compared to the $\mathrm{Al}$ electrodes. However, at neutral $\mathrm{pH}$, the removal of the parameters was higher in case of $\mathrm{Fe}$ electrode. The formation of $\mathrm{Fe}^{2+}$ iaq) ions and their posterior oxidation to $\mathrm{Fe}^{3+}{ }_{\text {aq }}$ caused the precipitation of $\mathrm{Fe}$ (III) hydroxide.

Effect of ST: The removal efficiency of COD and BOD with the constant operating conditions of CD $2.82 \mathrm{~A} / \mathrm{m}^{2}$, OT $40 \mathrm{~min}$., EA $160 \mathrm{~cm}^{2}$ and $\mathrm{pH} 7.5$ improved with an increase of ST from 30 to 90 mins. of BTMW. The maximum removal was observed for $\operatorname{COD}(92.35 \%)$ at the ST of 60 min., whereas for BOD $(84.88 \%)$, the maximum removal was at the ST of $30 \mathrm{~min}$. beyond which there was no significant removal (Fig. 6). The effect of ST on removal of these parameters with ET has not been given due consideration so far. Our earlier (Chopra and Sharma, 2012) study reported that there was a maximum removal of TD $(87.41 \%)$ and BOD (81.38\%) from the STS in the electrolytic cell under the optimum operating conditions of EA of $125 \mathrm{~cm}^{2}$, initial $\mathrm{pH}$ of 7, current density of 7.52 $\mathrm{mA} / \mathrm{cm}^{2}$, and operating time of $40 \mathrm{~min}$. with the use of $\mathrm{Al}$ electrodes.

E conomic evaluation: Electrical energy and electrode consumption are the important parameters in the economic evaluation of EC process. The operating cost of EC process using $\mathrm{Fe}-\mathrm{Fe}$ electrodes has been evaluated as described earlier for Al-Al electrodes (Chopra and Sharma, 2013). The use of Fe-Fe electrodes indicated that the energy consumption increased from $69.12 \mathrm{kwh} / \mathrm{m}^{3}$ to $108.48 \mathrm{kWh} / \mathrm{m}^{3}$ with an increase in EA $\left(80-160 \mathrm{~cm}^{2}\right)$ and $\mathrm{CD}\left(1.80\right.$ to $\left.2.82 \mathrm{~A} / \mathrm{m}^{2}\right)$ which in turn resulted in increase of the electrode consumption from $50.00 \times 10^{-5} \mathrm{~kg} / \mathrm{m}^{3}$ to $78.48 \times 10^{-5} \mathrm{~kg} / \mathrm{m}^{3}$ for the removal of COD and BOD from BTMW during ET . The cost for ET was found to be 54.29 Rs. $/ \mathrm{m}^{3} / 1.08 \mathrm{US} \$ / \mathrm{m}^{3}$ in terms of energy and electrode consumption with the optimum operating conditions of $\mathrm{CD}\left(2.82 \mathrm{~A} / \mathrm{m}^{2}\right), \mathrm{OT}(40 \mathrm{~min}$.), IED $(0.5 \mathrm{~cm}), \mathrm{pH}(7.5)$ and ST ( $60 \mathrm{~min}$.) of EC process (Table 1).

$\mathrm{K}$ inetic evaluation: It was revealed that an increase in the voltage form 5 to $40 \mathrm{~V}$ increased the rate constant for COD from 0.0018 to $0.0174 \mathrm{~min}^{-1}$ and for BOD from 0.0011 to $0.0167 \mathrm{~min}^{-1}$ for the ET of BTMW using Fe-Fe electrode combination. The increase in the rate constants may be ascribed to the decrease of COD and 
BOD The removal of COD and BOD exhibited pseudo first order kinetic with the significant correlation coefficients (>0.983) at maximum voltage of $40 \mathrm{~V}$ (Table 2$)$.

\section{Conclusion}

The removal of BOD and COD from BTMW using Fe electrodes was found to be dependent on voltage/CD, OT, IED, EA and initial $\mathrm{pH}$ during the ET. The optimal operating conditions of CD $2.82 \mathrm{~A} / \mathrm{m}^{2}$, OT $40 \mathrm{~min}$., EA 160 $\mathrm{cm}^{2}$ and $\mathrm{pH} 7.5$ yielded the maximum removal of COD $(92.35 \%)$ at the ST of $60 \mathrm{~min}$, whereas $\operatorname{BOD}(84.88 \%)$ at ST of 30 min. from the BTMW in the electrolytic cell. The kinetic rate constants for BOD and COD removal at various voltages indicated that pseudo-first-order kinetic is in good agreement with the significant correlation coefficients (>.98) at maximum voltage of $40 \mathrm{~V}$. The interesting thing was that there was no need of $\mathrm{pH}$ adjustment of the BTMW during ET as the optimal removal efficiency was close to the $\mathrm{pH}$ of 7.5. The operating cost for the ET of BTMW was found to be $54.29 \mathrm{Rs} . / \mathrm{m}^{3} / 1.08 \mathrm{US} \$ / \mathrm{m}^{3}$ in terms of energy and electrode consumption. Consequently, the ET can be applied as a post-treatment step to improve the quality of the final discharge in terms of BOD and COD removal by $\mathrm{Fe}-\mathrm{Fe}$ electrode combination.

\section{ACKNOWLEDGEMENTS}

The University Grant Commission, New Delhi, India is acknowledged for providing the financial support in the form of UGC Research Fellowship (F.4-1/2006 (BSR) 770/2007 BSR) to Mr. Arun Kumar Sharma.

\section{REFERENCES}

Aiyuk, S., Forrez, I., Kempeneer, D. L., Haandel, A. and Verstraete, W. (2006). Anaerobic and complementary treatment of domestic sewage in regions with hot climatesA review. Bioresource Technology, 97:2225-2241.

APHA (2005). Standard methods for the examination of water and wastewater, American Public Health Association, 21st edn. Washington, DC

Ashtoukhy, ES.Z.E.and Amin, N.K. (2010). Removal of acid green dye 50 from wastewater by anodic oxidation and electrocoagulation-A comparative study. J ournal of Hazardous M aterials, 179:113-119.

Bayramoglu, M., Kobya, M., Can, O.T. and Sozbir, M. (2004). Operating costs analysis of electrocoagulation of textile dye wastewater. Sep. Purif. Technol., 37: 117-125.

Chen X., Chen G. and Yue P. L. (2000). Separation of pollutants from restaurant waste water by electro - coagulation. Separation and Purification Technology, 19: $65-76$.

Chopra A. K. and Sharma A. K. (2012). Efficiency of turbidity and BOD removal from secondarily treated sewage by electrochemical treatment. J ournal of A pplied and Natural Science, 4 (2): 304-309.

Chopra, A. K. and Sharma, A. K. (2013). Removal of turbidity, COD and BOD from secondarily treated sewage water by electrolytic treatment Appl. Water Sci., 3(1):125-132.
Daneshava, N., Oladegaragoze, A. and Djafarzadeh, N. (2005). Decolorization of basic dye Solutions by Electrocoagulation: an investigation of the effect of operational parameters, J ournal of $\mathrm{H}$ azar dous M aterials, 129:116-122.

Daneshvar, N., Khataee, A.R., Amani, Ghadim, A.R. and Rasoulifard, M.H. (2007). Decolorization of C.I. acid yellow 23 solution by electrocoagulation process: investigation of operational parameters and evaluation of specific electrical energy consumption (SEEC). Journal of Hazardous Materials, 148: 566-572.

Daneshvar, N., Oladegaragoze, A. and Djafarzadeh, N., (2006). Decolorization of basic dye solutions by electro coagulation: An investigation of the effect of operational parameters; J ournal of Hazardous M aterials B, 129:116- 122.

Diaz B.C, Pardave P.M, Romo R.M and Martinez S (2003). Chemical and electrochemical considerations on the removal process of hexavalent chromium from aqueous media. J ournal of Applied Electrochemistry 33: 61-71.

Escobara, C., Cesar S.S. and Toral, M. (2006). Optimization of the electrocoagulation process for the removal of copper, lead and cadmium in natural waters and simulated wastewater. J . Environ. M anag., 81(4):384-391

Ghosh, D., Medhi, C.R., Solanki, H., and Purkait, M. K., (2008). Decolorization of Crystal Violet Solution by Electrocoagulation. J ournal of Environmental Protection Science, 2:25-35.

Gurses, A., Yalcin, M. and Dogar, C. (2002). Electro coagulation of some reactive dyes: a statistical investigation of some electrical variables. Waste M anagement, 22:491-499.

Holt, P. K., Barton, G. W., Wark, M. and Mitchell, C. A. (2002). A quantitative comparison between chemical dosing and electro coagulation. Colloids and Surfaces, 211:233-248.

Kobya, M. and Delipinar, S. (2008). Treatment of the baker's yeast wastewater by electrocoagulation. J . H azard M ater., 154:1133-1140.

Kobya, M., Can, O. T. and Bayramoglu M. (2003). Treatment of textile waste waters by electro coagulation using iron and aluminum electrodes. J ournal of $\mathrm{H}$ azardous $\mathrm{M}$ aterials, B100:163-178.

Kobya, M., Demirbas, E., Can, O.T. and Bayramoglu, M. (2006). Treatment of levafix orange textile dye solution by electrocoagulation. J. Hazard. M ater ., 132: 183-188.

Lettinga, G., Van Lier, Van, J.B., Buuren, J.C.L. and Zeeman, G. (2001). Sustainable development in pollution control and the role of anaerobic treatment. Water Sci. Technol., 44:181-188.

Li, X., Wang, W., Wang, M. and Yongyi, C. (2008). Electrochemical degradation of tridecane dicarboxylic acid wastewater with tantalum-based diamond film electrode. Desalination, 222: 388-393.

Lin, S.H. and Chen, M.L. (1997). Treatment of textile wastewater by electrochemical methods for reuse. Water Res., 31:868-876.

Mollah, M.Y.A., Morkovsky, P., Gomes, A.G.J., Kesmez, M., Parga, J. and Cocke, D. L., (2001). Fundamentals, present and future perspectives of electro coagulation. J ournal of Hazardous M aterials, B114:199-210.

Mollah, M.Y.A., Morkovsky, P., Gomes, A.G.J., Kesmez, M., Parga, J.. and Cocke, D.L. (2004). Fundamentals, present and future perspectives of electro-coagulation. J. Hazard Mater. B, 114: 199 - 210. 
Nasrullaha, M., Singh, L. and Wahida, Z.A. (2012). Treatment of sewage by electrocoagulation and the effect of high current density. Energy and Environmental Engineering J our nal, 1 (1):27-31.

Niam, F., Othman, M.F., Sohaili, J. and Fauzia, Z. (2007). Removal of cod and turbidity to improve wastewater quality using electrocoagulation technique. The Malaysian J ournal of A nalytical Sciences, 11:198-205.

Philippe R., Haenni, W. and Pupunat, L. (2003). Water treatment without chemistry. Chimia, 57(10):655-78.

Yi,Q. (2001). A sustainable technology for developing countryanaerobic digestion, In: Proc. 9th World Congress on Anaerobic Digestion-Anaerobic Conversion for Sustainability (Part 1), Antwerp, Belgium, September 2-6, 2001. pp. 23-30.
Rahmani, A.R. (2008) Removal of water turbidity by the electrocoagulation method. J . Res. H ealth Sci., 8(1) : 18-24.

Rajeshwar, K., Ibanez, J.G. and Swain, G.M. (1994). Electrochemistry and the environment. J ournal of Applied Electrochemistry, 24:1077-1091.

Tezcan, U., Ugur, U., Koparal S., Bakýr A.S. and Ogutveren, U.(2006). Electrocoagulation of olive mill wastewaters. Separ. Purif. Technol., 52 (1):136-141.

Vijayaraghavan, K., Ahmad, D., Yuzri, A. and Yazid, A. (2008). Electrolytic treatment of latex wastewater. Desalination, 219:214-221.

Zaroual, Z, Azzi, M. and Saib, N. (2006). Contribution to the study of electrocoagulation mechanism in basic textile effluent. J. Hazard. M ater., 131(1-3):73-78. 